\title{
Bank Failures And Public Policy
}

\section{R. ALTON GILBERT}

B ANK FAILURES since the fall of last year have caused a great deal of concern regarding both the soundness of banks and the effectiveness of current regulatory practices in this country. ${ }^{1}$ The largest bank failure in U.S. history occurred last year with the collapse of the Franklin National Bank of New York (total assets of $\$ 3.6$ billion). One of the immediate causes for the falure of Franklin National was large loan losses in foreign exchange transactions. However, Franklin National also had difficulty generating earnings ratios as high as banks of comparable size which were accepting the same risks." Fourteen other banks have failed or were forced into mergers since last fall, the largest being Security National Bank of Long Island (total assets of $\$ 1.8$ billion), which had large losses in real estate loans. Information on those failures and forced mergers is presented in Table I.

The recent experience with bank failures differs from what has occurred during most of the period since the early 1940s, when the few banks that did fail were primarily small banks. 3 Deposits of banks that failed during those years generally comprised less than one-hundredth of one percent of total deposits (see Table II). The share of total deposits in banks that failed has tended to be higher since the mid-1960s, rising to roughly one quarter of one percent in 1974. This changing pattern since the mid1960 s reffects failures of larger banks.

A primary objective of bank regulation in this country is prevention of bank failures. In addition,

1For a discussion of public concern over the soundness of banks, see Business Week, April 21, 1975, and Forbes, July I, 1975. One indication of the concem of investors abont the soundness of banks is the rapid decline in bank stock prices from spring to fall of 1974 . Investors got news of the financial difficulties of Franklin National in May of last year. An index of stock prices of New York City Banks fell at a 63.5 percent annual rate from April to Septenber of 1974 , compared to a 52.0 percent rate of decrease in the Standard and Poor's stock index daring the same period. The index of bank stock prices and the Standard and Poor's 500 composite stock index are presented in an accompanying chart.

"Sanford Rose, "What Really Went Wrong at Fraxklin National", Fortune (October 1974), pp. 118-21, 220-27.

"Note that the chart entitled "Bank Failures: 1934- 74 " and Table II refer to only those banks that have been declared falures by their govemment supervisors and do not include those forced to merge with larger banks due to financial difficulties even though technically solvent. This distinction accounts for the differences between the observations in Table I and those in Table II and the "Bank Failires" chart.

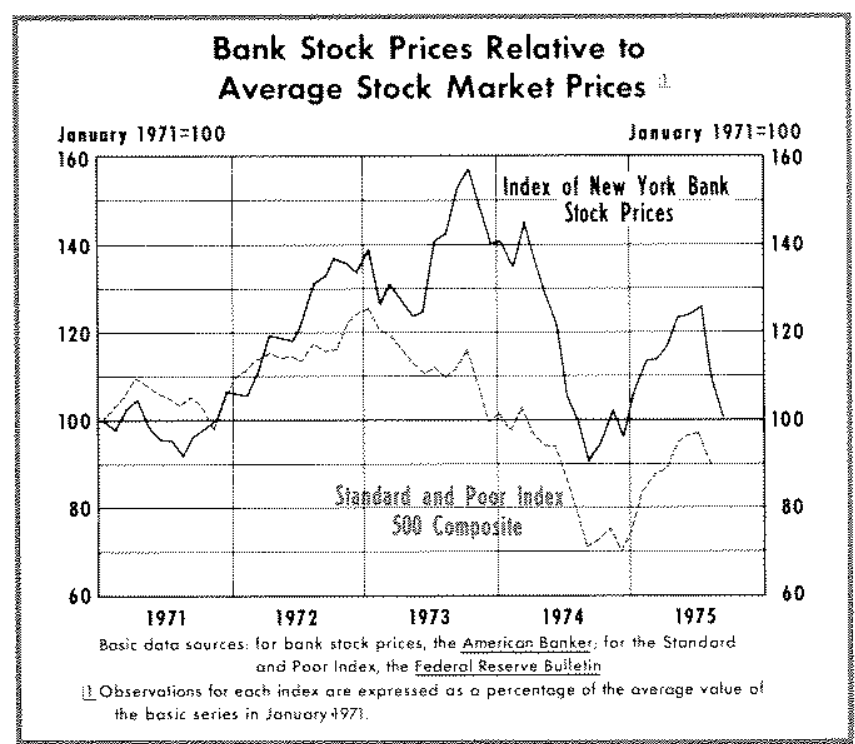

relaxation of some banking regulations has been recognized as another desirable policy goal. In recent years some regulations bave been relaxed to give banks greater freedom to respond to changing market conditions. As regulations are relaxed, however, banks have a tendency to assume greater risks and, hence, increase their vulnerability to failure. The goal of maintaining a low rate of bank failure, in turn, is placed in jeopardy.

These two policy goals for banking can be made more compatible by altering the program for Federal deposit insurance such that the premiums on deposit insurance are based upon the risks banks assume. As background to this proposed change, the causes of widespread bank failures are discussed, with reference to the experience of the $1930 \mathrm{~s}$, and the regula tory response to dealing with the vulnerability of the banking system to such failures is described. In addition, some actual and proposed changes in bank regulations are presented.

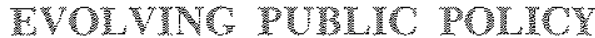 AFTECTNG BANK TALUTE}

\section{What he Bank Falure?}

Banks are officially declared failures, by the state or Federal agencies that charter them, when the net worth of a bank becomes zero or negative, or when a 


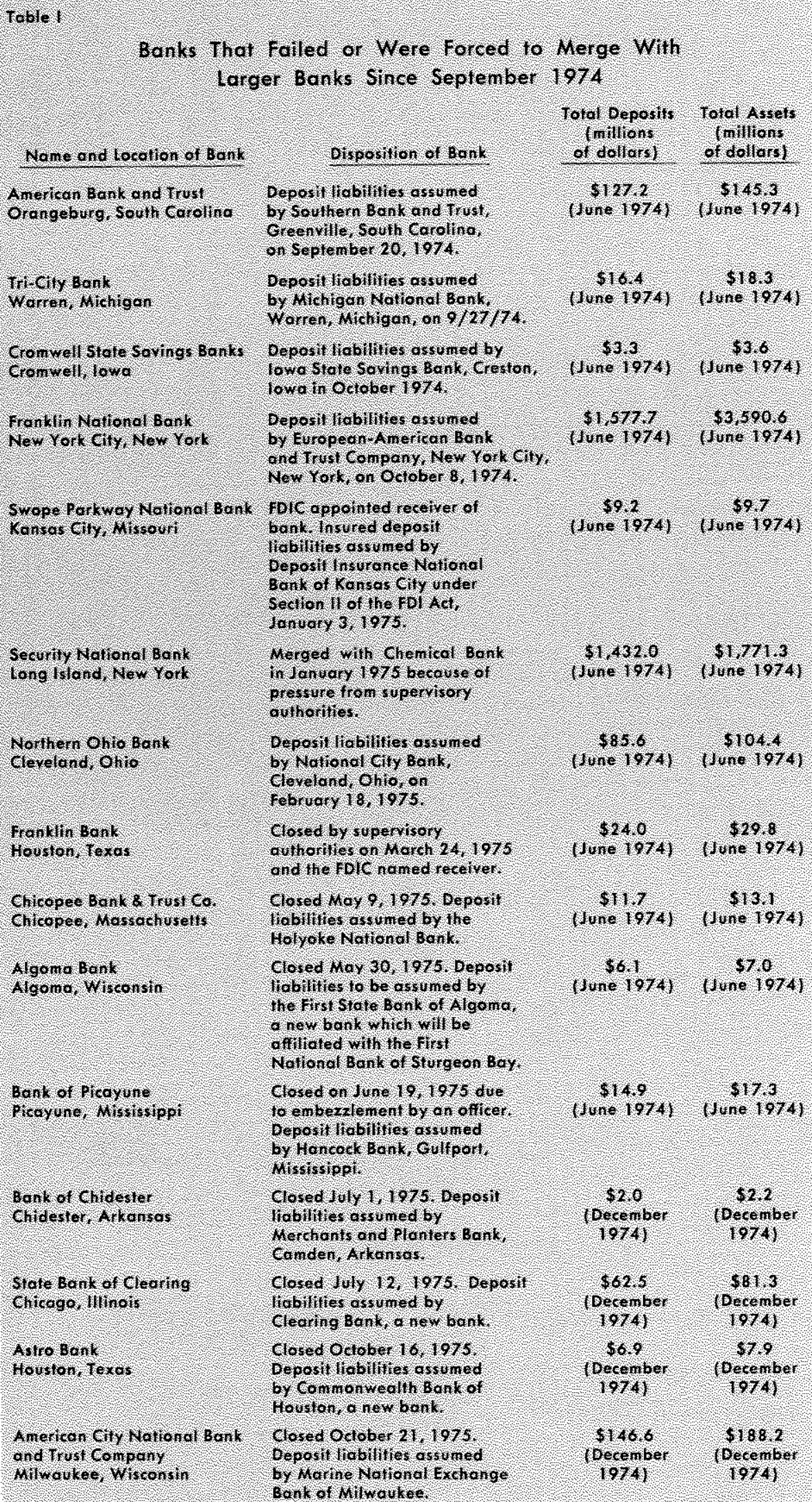

16mo ond $1001000,100 n$

A thentedr Bank and Wurt?

6rongebong, sootherolino

$70101011 \%$

Worent $1101100 \mathrm{n}$

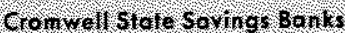
crom well $10 \%$ a

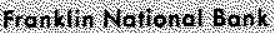

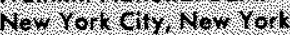

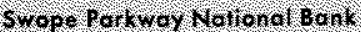

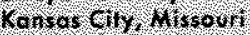

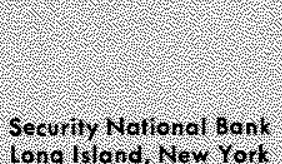

Woothentohto 30 .

clevelond ollio

Franlwit bank

100101,7 esos.

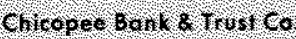

chloopeo, Mosscthureths

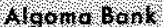

A, ono. Whisconsin

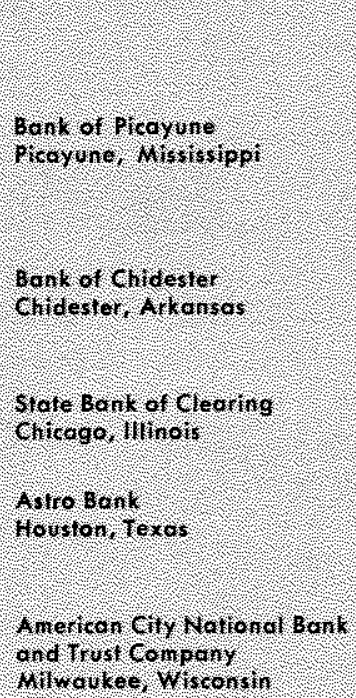

$01300,110 n$ or 0001

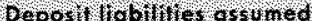

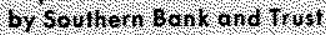

croentile, soulh sarolno,

on bepternber 20,1974

boposin labilines ars uned b. Wheroun Wollond $6 \mathrm{~cm}$. Waren, Wrolgon, on $9 / 27 / 74$

Deposillablwros ossuned ty

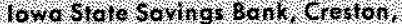
10,60 th Oetover 1974

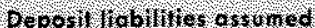

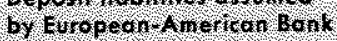

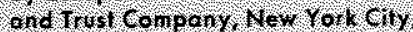

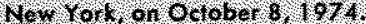

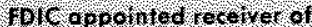

bont, insured deposil

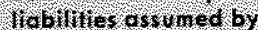

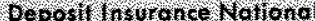

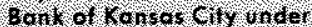

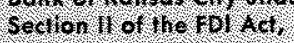

Jonuen 3,1973

Norged wh G Gentical 8 on

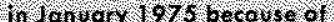

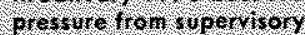
anthorities.

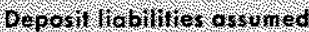

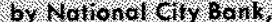

$610 \times 10,1,0,10,0$

Fetroon, 10, 1075

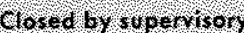

whontes on Morch 24,197

and the Hold nomed a reterwer

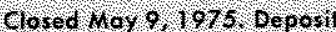

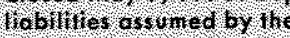

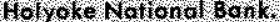

coved Wov 30,1975 Deposit

wow thes lo be on white o b

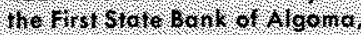

a new bonk whid will be

afthated whithe fits

Nollonal Bunk of Sturgern Bay.

Closech on hro 19,1975 dre

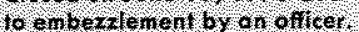

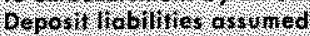

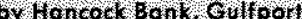

Mrsisslopl

dosed 10141,1075 , Debost

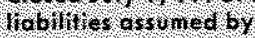

Morhont and ol aniers Bank

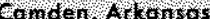

Closod Noty 12,1975 , Deposit

lic bithter o s a the d b by

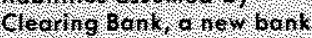

Glosed ow tober 16,1075

Deposil lobilitrex as oned

by Conthon we ell th 8 on k of

Hounton, o new bonk

clowed 0 $160 \mathrm{~b}, 21,1975$.

bepost habilitier as onded

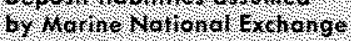

Bouk of HUlwatkat

Totaloposth

(twithions:

$0.00110 \mathrm{~s})$

01272

$10,0,1974$

316.

Wure 1974$)$ (wne 19741

$\$ 18$

$\$ 3$

Sune 107,

$\$ 10$

$\$, 57 \%$

100101974

r

001 ४ $२$ ४ 807

$10,10.19741$, $110 n e, 1974$

$41,432.0 \%$ V 11771,

Wone 1977, 7 nae 1974

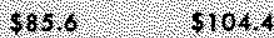

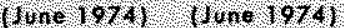

$12404 \checkmark \checkmark \checkmark, 00,8$

$10 \mathrm{ne} 1074)$ (1010 1974$)$

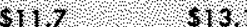

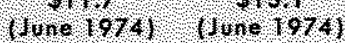

$\$ 61 ?$ ४ै $\$ 1 \%$

(une 1974$)$ (Une 1974$)$

$\$ 140$

0010197

5173

10.

Decermbe

1014

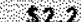

(D) $60 \mathrm{mbe}$

1974

$\$ 625$ ?ै? $\$ 00,3$

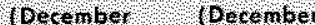

19741 ?ै?

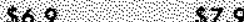

Obeanor 4 , oecembe

19741 ?

$5,40,6$

roecenbe

$1 \%$

$\$ 1882$

toed $\mathrm{nb}$

1974

situation threatens to make the net worth of a bank zero or negative. Such situations have one of the following three outcomes:

(1) The chartering agency closes a bank permanently. Depositors receive payment from the Federal Deposit Insurance Corporation (FDIC) for up to $\$ 40,000$ per deposit account. Customers with deposits over $\$ 40,000$ lose the uninsured portions of their accounts, unless there is some residual value when the FDIC disposes of the bank's assets.

(2) The chartering agency closes a bank, but its deposit liabilities and assets are assumed by another bank. In some cases, the FDIC either purchases assets of a failing bank which are of questionable value or insures the bank that is assuming the deposit liabilities from losses on the assets it acquires. No customers incur losses on their deposit accounts in this case. The banking organization which assumes deposit liabilities often begins offering banking services at the offices of the bank that failed. ${ }^{4}$

(3) Without officially declaring a bank to have failed, regulatory authorities arrange an emergency merger between a bank having financial difficulties and another bank. The merged bank assumes all of the deposit liabilities of the bank having financial difficulties.

4From 1934 (the beginning of Federal deposit insurance) through 1973,297 insured banks were closed permanently for liquidation and the deposit liabilities of 205 failing banks were assumed by other financial institutions. Through 1973 the deposits of insured banks that have failed less payment to the depositors of those banks amounted to about $\$ 25.3 \mathrm{mil}$. lion. However some of that amount will ultimately be recovered as the assets of closed banks are liquidated. Federal Deposit Insurance Corporation, Annwal Repont (1973), p. 5. 


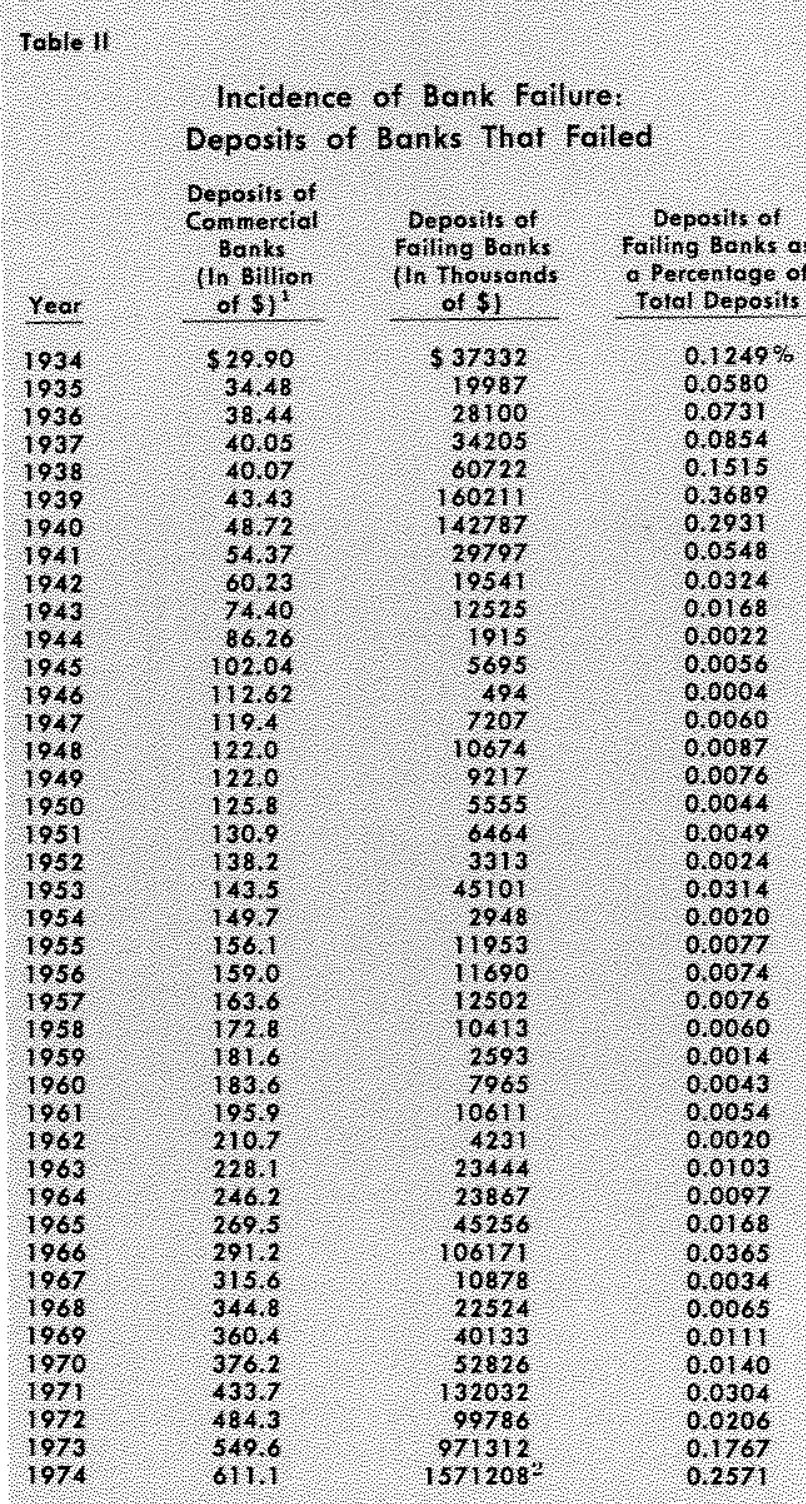

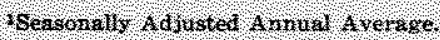

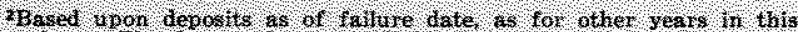

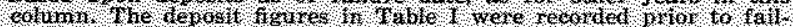
$1+10 \mathrm{mes}$

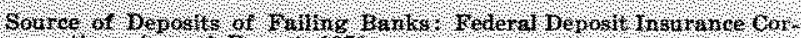

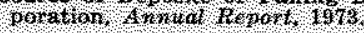

\section{Widespread Bank Fathures}

The most recent period of widespread bank failures in U.S. history was from 1929 to 1933 when the number of banks in operation declined by over one-third. ${ }^{5}$ The sequence of events that led to this general collapse of the banking system illustrates the process by which widespread bank failures can be generated.

5Milton Friedman and Amna I. Schwartz, A Monetary History of the United States, $1867-1960$ (Princeton, New Jersey: Princeton University Press, 1963), p. 299.
Although the stock market crash came in October 1929, the large rise in the rate of bank failures did not occur until October $1930 .^{6}$ The failure of several banks in the fall of 1930 created fear that other banks were unsound. ${ }^{7}$ Depositors began demanding conversion of their deposit balances to currency on a large scale.

Even a conservatively managed bank has limited ability to convert deposits to currency for a large fraction of its depositors. A bank generally cannot use its required reserves for such payments of currency since bank regulatory authorities regard these reserves as essential for a bank's continued operation. One source of currency for making payments to depositors is from selling assets. When many banks simultaneously experience large currency withdrawals, attempts of banks to obtain currency by selling securities will tend to drive down the prices of securities. If these runs continue long enough and the market values of securities fall far enough, even the most conservatively managed banks will tend to become insolvent as they suffer losses in liquidating their assets.

This process of several bank failures inducing fear of more failures, bank runs, declines in the value of bank assets, and then additional bank failures, occurred in three phases in the early 1930s. The last phase of this process came in the first three months of 1933.8

${ }^{6}$ As one indication that the public retained its confidence in commercial banks until the fall of 1930 , the ratio of bank deposits to currency rose during the period August 1929 to October 1930.

Ilbid, pp. 308-309.

8Ibid, pp. 308-332. Widespread bank failures were not inevitable in the early 1930 s when fear of insolvency of banks spread among bank customers. In the banking crisis of 1907 and in earlier banking crises, banks mutually agreed not to convert deposit balances to currency for their customers. During such periods, the public continued to use bank depos. its as money, and banks continued to offer most services, but for a while deposits could not be converted into currency. See Friedman and Schwartz, A Monetary History, pp. 156-68. One of the reasons for establishing the Federal Reserve System was to make such restrictions of conversion from deposits to currency unnecessary since the Federal Reserve was to provide sufficient currency to banks whenever there was a threat of large deposit withdrawals. The existence of the Federal Reserve as lender of last resort may have been a major reason why commercial banks did not mutually agree to restrict payments of currency in the early 1930s. However, the Federal Reserve failed to function in its role as lender of last resort during that period. There were some expansionary policy actions by the Federal Reserve inmediately after the stock market crash in 1929 and again in 1932, but these actions were not sufficient to offset the forces tendiry to reduce the money stock and bank credit. See Friedman and Schwartz, A Monetary History, pp. 305-6, pp. $322-4$. 


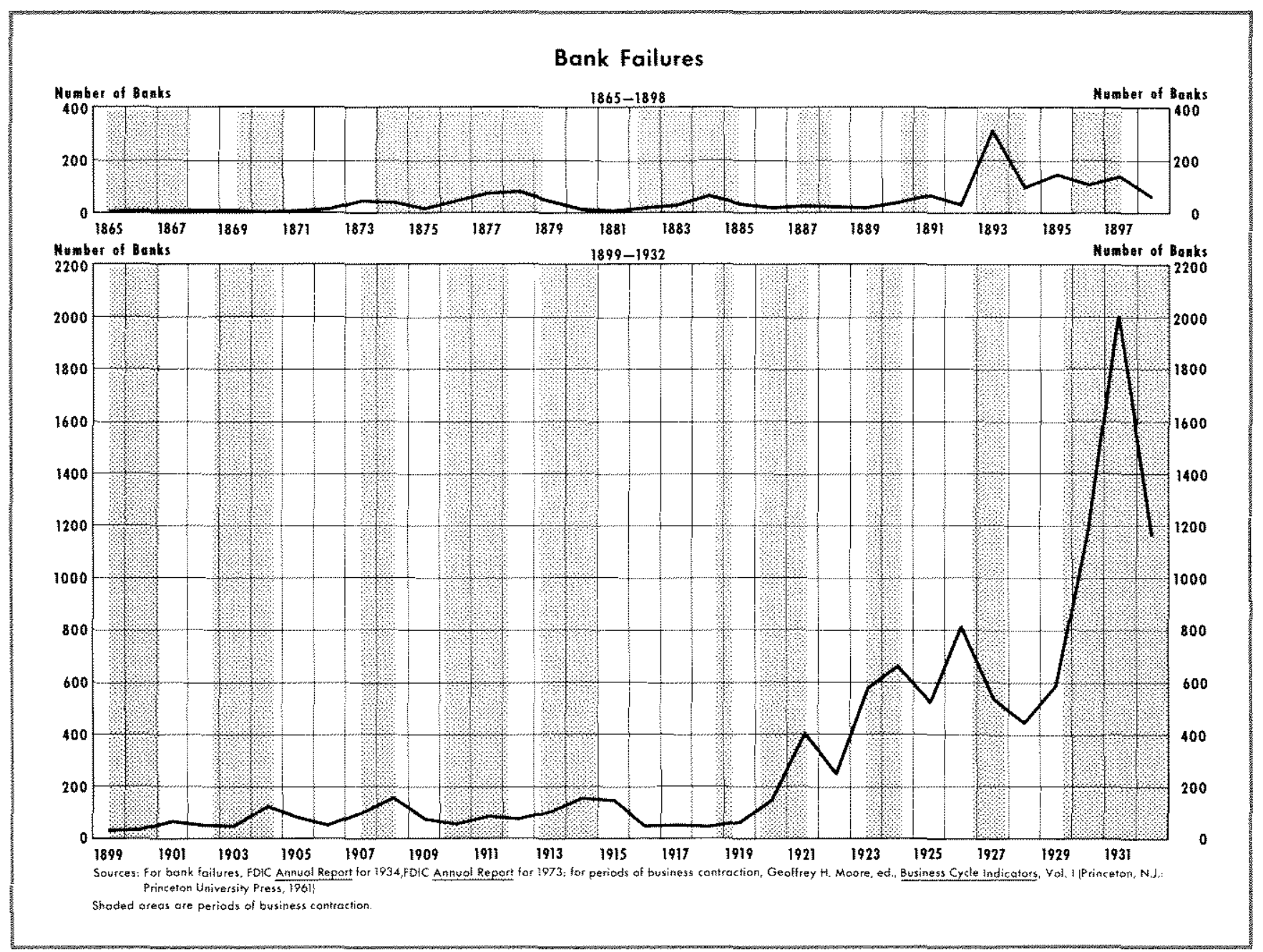

One important point to be emphasized from the process that generates widespread bank failures is that when the public loses confidence in the banking industry, forces which cause an individual bank to fail are, in general, independent of its prior investment policies. Both a bank that has invested in risky assets and one that has assumed little risk are vulnerable to failure in such an environment. Therefore, policies designed to deal effectively with widespread bank failures must involve more than simply requiring banks to acquire less risky assets.

\section{Bank Regulatory Pesponse to Widespread Falures}

The following discussion describes features of the bank regulatory policies which have been developed since the early 1930s that deal with the vulnerability of the banking system to widespread failures. Individual features of the regulatory policies are evaluated in other studies; such an evaluation is not the purpose of this paper. ${ }^{9}$ Presentation of bank regulatory policies as an interrelated system designed to prevent bank failures facilitates the analysis below of how proposals for financial reform would influence bank behavior and vulnerability to failure.

The most significant innovation in bank regulation during the 1930s was Federal deposit insurance, of-

"George I. Benston, "Interest Payments on Demand Deposits and Bank Imvestment Behavior," Joumal of Political Economy (October 1964), pp. 431-49; Benston and John T. Marlin, "Bank Examiners' Evaluation of Credit: An Analysis of the Usefulness of Substandard Loan Data," Journal of Monety, Credit and Banking (February 1974), pp. 23-44, Sam Peltzman, "Entry in Commercial Banking," Joumal of Law and Economics (October 1965), pp, 11-50, Peltzman, "Capital Investment in Commercial Banking and Its Relationship to Portiolio Regulation," Journal of Political Economy (January)

February 1970), pp. 1-26; Donald P. Jacobs, The tmpact of Examination Practices Upon Commercial Bank Lending Policies, Staff Analysis for House Committee on Banking and Currency, 88th Congress, 2nd Session, Washington, D.C., G.P.O., 1964; Lucile S. Mayne, "Supervisory Inflence on Bank Capital," Joumal of Finance (June 1972), pp. 637-51;

Hsiu-Kwang $W_{\text {n, }}$ "Bank Examiner Criticisms, Bank Loan Defaults, and Bank Loan Quality," Joumal of Finance (September 1969), pp. 697-705. 


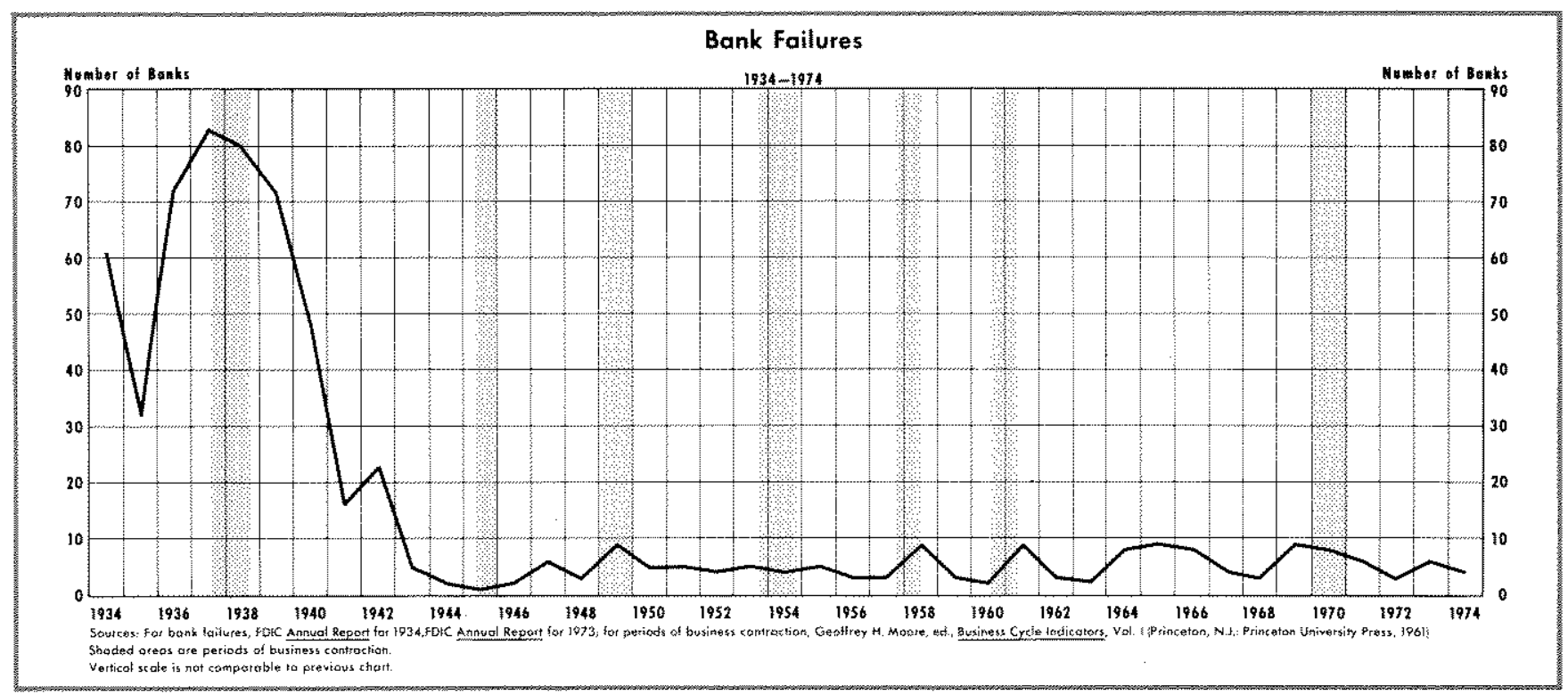

fered through the FDIC. Federal deposit insurance reduces the incentives for bank runs when some events occur which, in the period before deposit insurance, would have made depositors fearful about the safety of their deposits.

Although deposit insurance has been effective in preventing bank runs, prevention of individual failures is also a national policy objective. One important reason for attempting to keep bank failures at a low rate is to keep the payouts from the deposit insurance fund low, thus promoting public confidence in the ability of the deposit insurance fund to meet its obligations. The risks that banks assume must be constrained in some way in order to have a low rate of bank failure. The Federal deposit insurance program is not designed to constrain the incentives for banks to assume risks since the premium rate for deposit insurance does not vary among banks but is a given percentage of insured deposits. Since Federal deposit insurance provides a large degree of safety from bank runs, it may tend to induce banks to hold portfolios of assets with higher risks than if the banking system was less safe from bank runs.

The risks that banks assume are constrained by direct government regulation of bank behavior. A limit is imposed on the maximum loan that each bank can make to one customer which, by regulation, is a fraction of the banks capital. This regulation may cause banks to diversify their risks to a greater extent than they otherwise would. Banks are restricted from buying corporate stock, and there are some restrictions on the real estate loans that banks can make. Regulators examine banks to determine the quality of their assets and to enforce compliance with all regulations. As part of the examination process, examiners rate the quality of bank management, and occasionally exert pressure to change management. Regulators put pressure on banks to keep their capital-toasset ratios above minimum levels. ${ }^{10}$ All of these forms of regulation tend to impose the judgment of regulators on banks, reducing the ability of banks to respond to changing market conditions in investing their assets.

In addition, regulation of bank liabilities involves ceilings on interest rates that banks may pay on time deposits and prohibition of interest on demand deposits. An intent of these regulations is to increase bank profits, to remove the incentives for banks to acquire high risk assets, and to decrease the volatility of deposits. ${ }^{11}$ One important influence of this regulation is that levels of interest ceilings in relation to market rates influence the ability of banks to attract time deposits.

\footnotetext{
torthe penalties that bank regulators have for enforcing their capital adequacy standards include removal of bank officers and directors, cancellation of deposit insurance, and closing banks. These penalties are quite drastic and are seldom imposed. There is some evidence that bank regulators have little effect on the capital ratios of banks. See Sam Peltzman, "Capital Investment in Commercial Banking and Its Relationship to Portfolio Regulation," Joumal of Political Economy (Jantary/February 1970), pp. 1-26; Lucille S. Mayne, "Supervisory Infuence on Bank Capital," Joumal of Finance (Jume 1972), pp. 637-51,

'IGeorge Benston tested the hypothesis that banks which paid higher interest rates on deposits made more risky loans. The results of empirical tests led him to reject that hypothesis. See George J. Benston, "Interest Payments on Demand Deposits and Bank Investment Behavion," Joumal of Politi cal Economy (October 1964), pp. 431-49.
} 


\section{Effect of Bank Regulation on Fallures}

The bank regulatory scheme developed in the 1930 s contributed to a reduction in the rate of bank failure to relatively low levels by the early 1940 s. No more than 9 banks failed in any one year from 1943 through 1974 , compared with approximately 500 failures per year in the $1920 \mathrm{~s}$ (see accompanying chart). ${ }^{12}$ There has been no tendency for bank failures to cause loss of confidence in banks in general and to induce additional failures. The sort of failures that have occurred since the early 1940 s have often created public benefits since failure is one process of removing inefficient or dishonest bankers.

\section{Recent Developmenss an Bank Regulation, Behovior, and Implications for Falures}

Since the early 1940 s, bank failures have been caused primarily by embezzlement, fraud, bad management, and assumption of high risks. ${ }^{13}$ This section focuses on the risk aspect of bank failures. Several developments in recent years have reduced regulatory constraints on banks without changing incentives for banks to accept risks, and many banks have responded by accepting higher risks. The following discussion includes only a few of the important changes in regulation and bank behavior which have been taking place.

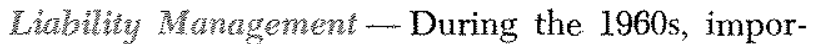
tant changes took place in the sources of bank funds. Some banks began attracting a large share of their deposit liabilities by issuing certificates of deposit, and the volume of transactions in Federal funds was greatly expanded, as shown in the accompanying chart. Banks were given greater freedom to attract funds by issuing large CDs in 1970 when interest ceilings were removed on short-term time deposits of $\$ 100,000$ or more and in 1973 when interest ceilings were removed on large time deposits of all maturities. Another source of funds that banks began to use dur-

\footnotetext{
12Federal Deposit Instrance Corpotation, Annual Report, 1934, pp. 93-94.

13 For a disctission of the causes for individual bank failures each year, see the Anntal Reports of the Federal Deposit Insurance Corporation. For an additional discussion of the reasons for bank failures, see Recent Bank Closings, Hearings before the Committee on Banking and Currency, House of Representatives, March 9, 1971, pp. 33-37; Robert E. Barnett, "Anatomy of a Bark Failure," The Magazine of Bank Admintistration (April 1972), pp. 20-23, 43; George J. Benston, Bank Examination (New York University, The Bulletin, No, 89-90, May 1973); and John J. Slocum," Why 57 Insured Banks Did Not Make It - 1960 to 1972," Journal of Commercial Bank Lending (August 1973), pp. 44-56.
}

ing the late 1960 s was that of bank related commercial paper, which is sold by subsidiaries of banks or bank holding companies (see chart).

Banks which attract large shares of their funds from sources that are not fully insured are vulnerable to losing such funds quickly if investors discover that those banks are having financial difficulties. ${ }^{14}$ Therefore, many banks have become more vulnerable to liquidity crises due to their practices of attracting large shares of their funds for investment by issuing large CDs and by borrowing in the Federal funds market.

Changes in Regulatons Affecting Bank Aves and Capial - Important changes have also been made in the regulation of assets that banks may acquire and in the capital structure of banks. Many of these changes have been initiated by the Comptroller of the Currency, and similar regulations have been adopted by the other bank regulatory agencies. Several such changes discussed in the 1963 Annual Report of the Comptroller are listed below.

(1) Lending limits, the largest loan banks can make to any one customer, were increased for many banks.

(2) National banks were given greater freedom in making real estate loans.

(3) The types of general obligation bonds of state and local governments that national banks could underwrite were expanded.

(4) National banks were allowed to count longterm debt which is subordinated to deposit liabilities as part of their capital ${ }^{15}$ In cases of bank liquidation, holders of subordinated debt receive payment only if all depositors receive full payment. Previously, bank regulators considered only equity capital to be bank capital.

The first three changes listed above influence the riskiness of assets that banks may acquire. Regulations concerning debt as bank capital also have several important implications for the risk exposure of banks. Suppose that for some reason a bank has a large reduction in the value of its assets. The feasibility of the bank accunulating enough capital out of retained eamings to again be considered a viable or-

\footnotetext{
${ }^{14}$ The CDs issued by most banks are insured by the FDIC up to $\$ 40,000$ per depositor. Federal funds borrowings are not instared by the FDIC.

15The Federal Reserve and the FDIC recently proposed changes in regulations which would specify the role of debt as capital for banks regulated by those agencies.
} 


\section{Sources of Funds for Banks Engaged in Liability Management}

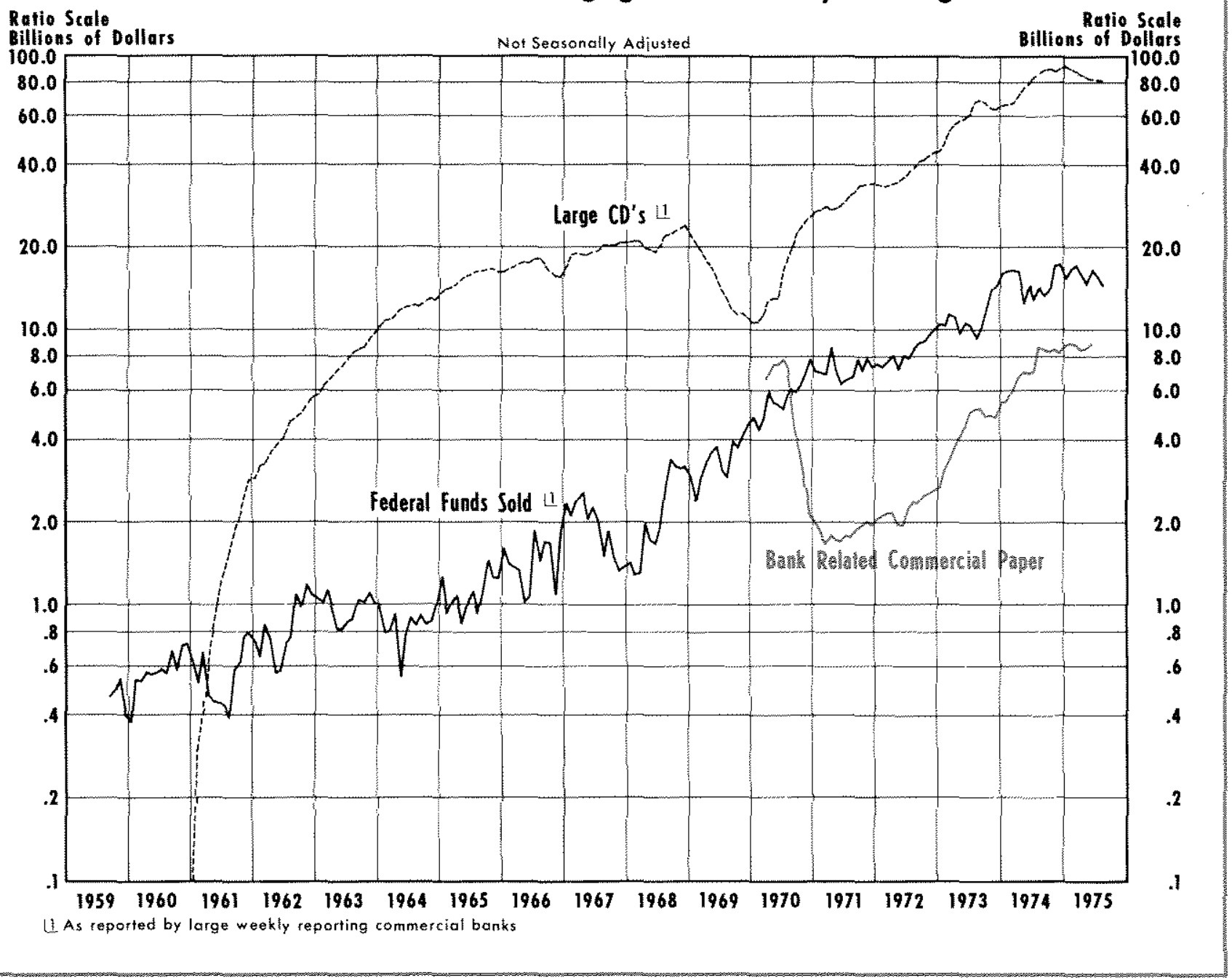

ganization by regulators could depend upon how much debt the bank has in its capital structure. Interest payments on debt capital and its ultimate retirement are obligations that the bank must meet in order to remain solvent, whereas dividend payments can be postponed, and there is no obligation to retire equity capital. Another implication of regulators considering long-term debt to be bank capital is that banks can increase their lending limits by issuing such debt, since lending limits are based upon the total capital accounts of banks.

Acquistions of Nonbagking Firms by BHCs - Another recent development which has implications for the risks of bank falures is the acquisition of nonbanking firms by bank holding companies (BHCs). Since 1970 the Federal Reserve Board has had the responsibility of determining the activities in which
BHCs may engage. ${ }^{16}$ Table III lists the currently approved activities. The expansion of BHCs into nonbanking industries creates possibilities for financial difficulties of nonbanking subsidiaries to adversely affect bank subsidiaries. Many customers of a subsidiary bank may withdraw their deposits if a nonbank subsidiary of the $\mathrm{BHC}$ experiences financial difficulties. One reason for depositors of a subsidiary bank to start a run on the bank is they may assume

\footnotetext{
16 In 1956 the Federal Reserve Board received legislative authority to regulate the acquisitions of firms that own controlling interest in two or more banks. "These holding companies were not allowed to engage in activities other than banking. Holding companies owning only one bank were free to make whatever acquisitions of nonbanking fims they wanted before 1970 . The BHC Act of 1970 gives the Federal Reserve Board anthority to regulate the acquisition of all BHCs with the possibility of BHCs acquiring firms in industries other than banking which the Board rules to be closely related to banking. BHCs must get prior approval from the Board for each such acquisition.
} 


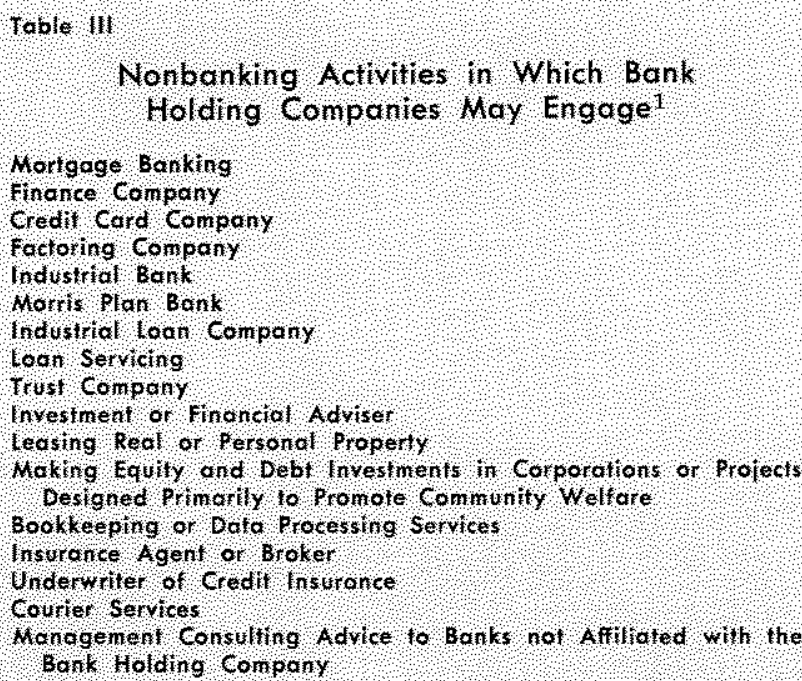

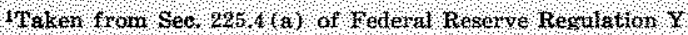

that the subsidiary bank has made the same bad investment decisions as the nonbank subsidiary. Another reason depositors may react in that. way is because they may assume that the subsidiary bank will use its resources to help the nonbank subsidiary in financial difficulty, even though several regulations restrain subsidiary banks from taking such actions.

The possible risks to banks of affiliation with a $\mathrm{BHC}$ are illustrated in the case of the Beverly Hills National Bank and its parent corporation. The BHC had financed large loans to a real estate developer by selling its own commercial paper. When the real estate developments became unprofitable, the BHC had difficulty refinancing its commercial paper debt. The bank lost deposits as the financial position of the BHC became more widely known, although the bank itself was solvent according to the analysis of the Comptroller of the Currency. The holding company sold its interest in the bank to the Wells Fargo Bank to pay off its debts. ${ }^{17}$

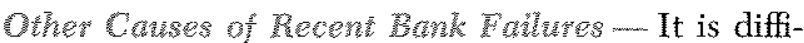
cult to determine the role of the above changes in regulations and bank behavior in the recent bank falures because there have been several other forces at work. The recent recession began in the fall of 1973, and it is during recession periods that large loan losses make some banks insolvent. Historical evidence in the accompanying chart indicates a tendency for bank failures to rise when the rate of economic activity declines. In addition, the risks of speculation in foreign exchange have been greater since 1971 when

1TAmerican Banker, Jantary 2 and 23, 1974. the world monetary system was switched from fixed to floating exchange rates. The failure of Franklin National provides an example of the influence that foreign exchange speculation can have on bank earnings and capital.

\section{Some Recent Proposals for Puner Relaration of Constranis on Bank Behavion}

Proposals for financial reform which have received much attention in the past few years may indicate the future course of bank regulation. Proposals for financial reform by the Hunt Commission call for relaxation of several banking regulations which affect various types of activities in which banks may engage and the types of assets they may acquire. ${ }^{18}$ The Financial Institutions Act of 1975 proposes similar relaxation of regulations on real estate loans and community development projects.

Neither group of proposals for financial reform would alter the way in which deposit insurance premiums are calculated. Therefore, these proposals, hike several changes in regulation in recent years, would move the banking system in the direction of fewer constraints without reducing the incentives of banks to accept high risks; the degree to which such proposals would affect bank safety is uncertain.

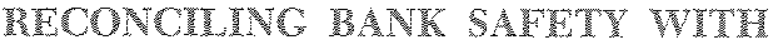 RELAXATION OF REGULATONS}

Bank regulation has changed in recent years to give banks greater freedom in attracting funds and selecting assets, and proposals currently under consideration indicate that there may be fewer regulatory constraints on banks in the future. However, if a low rate of bank failure and a solvent deposit insurance fund also continue to be important objectives of public policy, new forms of bank regulation must be implemented to restrain the risks that some banks would be induced to assume.

\footnotetext{
14Ste The Report of the President's Commission on Financial Structure and Regulation (Washington, D.C.: United States Government Printing Office, 1971), pp. 41-43. The Hunt Commission proposed, among other things, that (1) commercial banks and their subsidiaries be permitted to engage in a yariety of nonbanking activities of the type approved for BHCs by the Federal Reserve Board; (2) special statutory and regtlatory restrictions on real estate loans be abolished; (3) commercial banks be pernitted to invest in any assets up to 3 percent of total assets or 30 percent of eapital, surplus, and undivided profits, whichever is less; (4) anthority to underwrite revenue bonds be expanded; (5) commercial banks be permitted to make equity investments in community rehabilitation and development corporations in amounts up to 5 percent of capital, surplus, and undivided profits.
} 
These objectives could be achieved through a prom gram of charging banks deposit insurance premiums based upon the risks they assume. ${ }^{19}$ Regulation of bank behavior could be eliminated. Individual banks would be free to choose the degrees of risk they prefer. Most banks would probably not accept high risks if deposit insurance premiums were set high enough to compensate the deposit insurance fund for the risks involved. Whatever would be the choices of banks in accepting risks, the most important consideration is that public confidence in the capacity of the deposit insurance fund to meet its obligations prevents bank runs, and under this plan the solvency of the insurance fund would be protected by charging banks premiums that are high enough to cover their risks of failure.

The Hunt Commission Report presents the common arguments against variable deposit insurance premiums in the following quote:

The Commission rejected the variable rate proposal. It recognizes that differences in risk of failure exist and that its recommendation for liberalizing the regulations relating to the asset, liability and capital structures of financial institutions would probably increase these differences. The problem is a practical one. The Commission does not see how differences in risks can be evaluated with sufficient precision to be adequately reflected in insurance assessments. Further, the Commission believes that assessments might be used, albeit unintentionally, to penalize innovative institutions. New and different functions might be regarded as high risk functions. Finally, knowledge that some institutions were paying higher assessments than others could weaken public confidence in those institutions, which would defeat the purpose insurance was designed to achieve. ${ }^{20}$

Sam Peltzman has answers for these arguments. ${ }^{21}$ The evaluation of assets by bank examiners could be used as the basis for setting deposit insurance premiums. As to the argument that innovative institutions

19For other discussions of this proposal, see Thomas Mayer, "A Graduated Deposit Insurance Plan," Review of Economics and Statistics (February 1965), pp. 114-116; Clifton $\mathrm{H}$. Kreps, Jr. and Richard F. Wacht, "A More Constructive Role for Deposit Insurance," Journal of Finance (May 1971) pp. 605-13; Sam Peltzman, "The Costs of Competition: An Appraisal of the Hunt Commission Report," Journal of Money, Credit and Banking (November 1972), pp. 10014. Ronald D. Watson, "Insuring Some Progress in the Bark Capital Hassle," Business Review, Federal Reserve Bank of Philadelphia (July-August 1974), pp. 3-18.

-opresident's Commission on Financial Structure and Regulam tion, p. 74.

"1Sam Peltzman, "The Cost of Competition: An Appraisal of the Hunt Commission Report," Joumal of Money, Credit and Banking (November 1972), pp. 1001-4. would be penalized with higher insurance premiums, Peltzman maintains that such penalties would be only temporary until the insurance agency would adjust the premiums to actual experience. Peltzman also argues that with information on deposit insurance premiums becoming public knowledge, banks would have strong incentives to cater to the degree of risk aversion desired by their depositors.

\section{SUMMAR}

An appropriate objective of public policy regarding bank regulation is prevention of widespread bank failures. The money stock and bank credit have declined during past periods of widespread bank failures, disrupting economic activity. In the past, large numbers of banks have failed when some events, such as the failure of several banks or one large bank, made depositors fearful about the soundness of all banks, inducing them to demand currency for their deposits. That response tended to make even more people fearful about the soundness of their banks, creating runs on banks.

In this country the most recent experience with widespread bank failures was in the period 1930-33. Ctrrent regulatory policies were largely developed in the $1930 \mathrm{~s}$ in response to that experience. A central feature of these policies is Federal deposit insurance, which has greatly reduced the risks of bank runs. The deposit insurance premiums of banks are calculated as a given percentage of insured deposits. The risks that insured banks assume are controlled by direct regulation of bank behavior.

In recent years there has been some relaxation of bank regulation, giving banks greater freedom to compete in attracting deposits and investing their assets. However, there have been no changes in regulatory policies which would induce banks to restrain the risks they assume. If it is in the public interest to relax direct regulation of the risks that banks may assume and yet keep the bank failure rate low and the deposit insurance fund solvent, one appropriate change in policy would be to begin charging each bank a deposit insurance premium based upon the risks that it assumes. Such a policy would give banks greater freedom to respond to market forces in investing their assets while reducing their incentives to assume high risks. The premiums would be set high enough to compensate the insurance fund for the risks of failure that banks assume. 